\title{
PRESENT STATUS OF VIRUS INFECTIONS OF PEPPERS IN PUERTO RICOI
}

The occurrence of phytopathogenic viruses on peppers in Puerto Rico was first reported by $\mathrm{Cook}^{2}$ in 1929 . In 1941 Roque and Adsuar ${ }^{3}$ studied a virus which induced mosaic, stunting and fruit malformation in pepper plants. In 1971 Adsuar et al. ${ }^{4}$ described another mosaic disease of peppers and more recently Perez ${ }^{5}$ found tobacco etch virus affecting this crop in the Island.

In general, pepper viruses induce mottling of the leaves, stunting and fruit malformation. Other symptoms may appear sometimes, depending on the strain of the virus present. ${ }^{6}$ Simons ${ }^{7}$ stated that the three most important viruses of pepper in the United States, namely, potato virus $\mathbf{Y}$, tobacco etch and cucumber mosaic, take a 10 to 50 percent toll of pepper plants. In Puerto Rico the condition is more serious and a high percentage of pepper fruits are lost. Nevertheless, small farmers reap several harvests from virus diseased plants, although they observe that the yield and quality of fruit diminish heavily, sometimes down to 10 percent. The authors estimate the incidence of pepper virus diseases in Puerto Rico to range from 15 to 100 percent infection in most of the plantings they observed.

The Agricultural Experiment Station is actively engaged in conducting a research program directed toward the increased production and improvement in quality of horticultural crops. An Island-wide survey of the pepper virus disease situation thus became indispensable to furnish a basis for the initiation of a breeding program designed to develop resistant, high-yielding varieties. Pepper leaf samples were taken from plantings at 31 municipalities comprising 57 barrios surveyed during 1971-72 in the northern, central, eastern, southern and southwestern parts of the Island.

Each sample collected in the survey consisted of leaves from four or five different plants exhibiting virus symptoms. The samples were studied serologically, using the tube precipitin test to identify the viruses. The samples were kept in plastic bags in a portable ice chest. The chilled leaves were brought to the laboratory and placed in a refrigerator the day collected.

1 Manuscript submitted to Editorial Board May 22, 1973.

${ }^{2}$ Cook, M. T., Annual Rept. Ins., Exp. Sta. Dept. of Agriculture and Labor of Puerto Rico, Fiscal year 1927-28, p. 65, 1929.

(3oque A., and Adsuar J., Studies on the mosaic of peppers (Capsicum frutescens) in Puerto Rico, J. Agr. Univ. P.R. 25 (4) : 1-11, 1941.

- Adsuar J., Pérez J. Enrique, and Cortés-Monllor A., A new virus disease of peppers in Puerto Rico, J. Agr. Univ. P.R. 55 (4) : 405-10, 1971.

5 Pérez J. Enrique, unpublished data, 1970-71.

6 Simons, J. N., Peppers, Virus Control, American Vegetable Grower, pp. 19-20, February 1967.

7 Ibid. 
The following morning, $7 \mathrm{~g}$ of tissue from each sample were ground in sterile mortars. Crude sap from the finely ground tissue was then expressed through a double layer of gauze into a small glass funnel inserted in a plastic test tube. To the crude sap, $7 \mathrm{ml}$ of a 15-percent dibasic sodium phosphate solution were added and thoroughly mixed. This is a modification of Feldman's method for the microprecipitin test ${ }^{8}$ which consists of pouring the crude sap into the same amount of phosphate. The liquids were mixed with individual applicators and centrifuged for 20 minutes at $6,000 \mathrm{rpm}$ in a No.

TABLE 1.-Serological reactions of 914 pepper samples collected during 1971-78 in Puerto Rico

\begin{tabular}{cccc}
\hline Positive & \multicolumn{2}{c}{ Antisera and percent of positives to- } & Negative \\
\hline & Single infections & Mixed infections & \\
& PRPMV1 & PRPMV; TEV & \\
& $640(86 \%)$ & $59(7.8 \%)$ & \\
TEV & TMV; VPLLT & \\
& $21(2.8 \%)$ & $9(1.2 \%)$ & \\
& VPLT & PRPMV; VPLLT & Total negatives \\
Total positives & $3(0.4 \%)$ & $6(0.8 \%)$ & 167 (18\%) \\
$747(82 \%)$ & TMV & PRPMV; TMV & \\
& $1(0.1 \%)$ & $4(0.5 \%)$ & \\
& & PRPV; VPLLT; TMV & \\
& & $2(0.2 \%)$ & \\
& & PRPV; VPLLT; TEV & \\
& & $1(0.1 \%)$ & \\
& & PRPV; TMV; TEV & \\
& & $1(0.1 \%)$ &
\end{tabular}

1 PRPMV = Puerto Rican Pepper Mosaic Virus.

2 TEV = Tobacco Etch Virus.

- VPLLT = Virus from peppers producing local lesions in tobacco.

- TMV = Tobacco Mosaic virus.

813 angled-head rotor in an International Model UV centrifuge. The clarified saps were decanted and placed in the refrigerator until the following day for further clarification. The precipitates formed during the night were removed by centrifuging at $2,500 \mathrm{rpm}$ for 10 minutes as described above. About $0.3 \mathrm{ml}$ of the clarified supernatant of each sample was poured by means of a capillary pipette into a $6-\mathrm{mm} \times 50-\mathrm{mm}$ test tube containing an equivalent amount of antiserum to the respective viruses: Tobacco mosaic virus (TMV), Puerto Rican pepper mosaic virus (PRPMV), virus from peppers producing local lesions in tobacco (VPLLT), tobacco etch virus

8 Feldman, J. M., Serological diagnosis of virus present in peppers (sp.) Univ. Nac. de Cuyo Fac. Cienc. Agr. Rev. 12Aq (1): 171-2, 1965. 
(TEV) and normal rabbit serum. All sera were prepared against partially purified preparations of the aforementioned viruses. The antisera were diluted 1/40 in saline for the tests. The mixtures of individual saps and antisera were incubated at $37^{\circ} \mathrm{C}$. The tubes were checked for presence or absence of precipitation 1,2 and 3 hours after incubation.

Results of the survey are shown in table 1. PRPMV was the most prevalent virus. It was found in 82 percent of the total number of samples and 86 percent of the total number of positive serological reactions. The table also shows several mixed infections in which PRPMV was present. The findings on the prevalence of PRPMV are in agreement with the situation as reported by Roque and Adsuar in $1941 .^{\circ}$

The detection of TEV, VPLLT and TMV, in both single and mixed infections is of interest. Although found in a much lower frequency than PRPMV these viruses are indeed important. The transmission of PRPMV and TEV in a nonpersistent manner by aphids ${ }^{10}, 11$ coupled with the lack of information on the mode of transmission of VPLLT, appears to make the application of chemicals for the control of vectors a meaningless effort and points to the need for the development of resistant varieties. In addition, control measures for these viral infections should also include the elimination of sources of inoculum. ${ }^{12}$ within the immediate vicinity of pepper plantings, such as weeds and old, diseased pepper plants.

\author{
J. Enrique PErez \\ Department of Phytopathology and Bolany \\ Heber Irizarry \\ Department of Plant Brecding \\ Amelia Cortés-Monllor \\ Department of Phytopathology and Bolany
}

- Roque, A., and Adsuar, J., loc. cit.

10 Roque, A., and Adsuar, J., Joc. cit.

"Simons, J. N., loc. cit.

12 Ibid. 